\title{
THE USE OF HOVERING AS A SEARCH METHOD BY THE NORTHERN SHRIKE*
}

\author{
by Martin K. McNicholl, Department of Zoology, \\ University of Alberta, Edmonton
}

In his treatment of the Northern Shrike (Lanius excubitor), Bent $(1950: 120)$ stated that this species "has two principal methods of hunting, watchful waiting and active pursuit." S im il a $\mathrm{r}$ statements have resulted from more recent studies of this species in North America (Cade 1962 ; 1967) and in Europe (Mester 1965 ), and from earlier studies of the Loggerhead Shrike (L. ludovicianus) by Miller (1931). Miller (op. cit.: 211) and Cade (1967: 31) also described Loggerhead and Northern Shrikes respectively as sometimes hovering over a spot where prey has been sighted. Miller suggested that this method may serve as a searching device to allow the bird to judge better the rest of the attack. Zimmerman (1955:205) believed that hovering behaviour was more common in the Northern Shrike than in the Loggerhead Shrike, an impression shared with Cade (pers. comm., 1972).

Bent (loc. cit.) stated that "mice may be secured by hovering over the fields . . .", possibly suggesting a method of searching for previously undetected prey. Trautman's statement (in Zimmerman loc. cit.) that the Northern Shrike "habitually stops and flutters in a stationary position in mid-air, as does the Sparrow Hawk (Fulco sparverius)" may also refer to search behaviour. However, neither of these statements clearly referred to search for previously undetected prey, and both could be interpreted as referring to the final securing of prey detected by other methods. Studies by Thielcke (1956) indicate that this species even continues to use a watchful waiting method for capturing mice previously detected from a distance by waiting on the ground near the site of the mouse's

*Publication No. 17 of the University of Manitoba Field Station, Delta, Manitoba. disappearance. L a w r e n c e (1926) stated that Northern Shrikes, if unsuccessful in using the watchful waiting method from trees or other high perches near stubble fields, will sometimes hover "for ten seconds or so" to more closely inspect the stubble. Otherwise, hovering as a method of prolonged searching for previously undetected prey does not appear to have been described for this species.

On December 28, 1969, Harold R. Bauer and I observed a Northern Shrike hovering for 20 minutes over an open, marshy field at distances varying from 50 to 150 yards from the nearest tree. This was at the University of Manitoba Field Station at the Delta Marsh, Manitoba. It repeatedly hovered over one spot for a few seconds, then flew a few yards and hovered over another spot for a few more seconds, and so on. When it changed locations, it sometimes stayed at the same level in relation to the ground, but more frequently increased or decreased its height slightly, varying from 10 to 30 feet above ground, in much the same manner as a foraging Forster's Tern (Sterna forsteri) hovering over open m a r s h (McNicholl 1971:607-608). The shrike finally plunged to the ground as if after a target, and did not appear again before we left, suggesting that it had secured prey. As there were no small birds flying over the field, I suspect the shrike was hunting for small mammals, such as voles (Microtus).

'The hovering posture that we saw was similar to that described for a Northern Shrike by Lawrence (op. cit.), who stated that "The shrike when hovering appears to be almost standing on its tail, the body held at an angle of 15 degrees with the tail three-quarters spread, nearly straight down. The wings beat furiously ..." 
Bent's (1950:154) description of a Loggerhead Shrike "hanging suspended in the air on rapidly vibrating wings" also applies well to the bird observed by us.

It is perhaps significant that our observation took place over an open field, away from trees or other high perches, where neither of the main hunting methods would be suitable. Although not previously described in the literature, the behaviour described above has also been observed in the Northern Shrike on New York wintering grounds and Alaska breeding areas (T. J. Cade, pers. comm., 1972). Similar hovering behaviour frequently is used over wide expanses of High Arctic tundra by Long-tailed Jaeger (Stercorarius longicaudus) (P. S. Taylor, pers. comm.), and over open fields by Roughlegged Hawk (Buteo lagopus) and Sparrow Hawk (pers. obs.; see also Bent 1937:276; 1938:114; numerous other references).

\section{Acknowledgments}

I should like to thank Drs. Thomas J. Cade, Roger M. Evans, and Robert W. Nero for their comments on the manuscript, Peter J. Cowan for loaning the British literature to me, and Reto Zach for translating Thielcke's paper. Philip S. Taylor kindly added his observations on hovering by Longtailed Jaegers.

\section{LITERATURE CITED}

Bent, A. C. 1937. (Dover ed. 1961). Life histories of North American birds of prey. Part I. U.S. Nat. Mus. Bull. 167. 409 pp.

Bent, A. C. 1938. (Dover ed. 1961). Life histories of North American birds of prey. Part II. U.S. Nat. Mus. Bull. 170. 482 pp.

Bent, A. C. 1950. (Dover ed. 1965). Life histories of North American wagtails, shrikes, vireos, and their allies. U.S. Nat. Mus. Bull. 197. $409 \mathrm{pp}$.

Cade, T. J. 1962. Wing movements, hunting, and displays of the Northern Shrike. Wilson Bull. 74 :386-408.

Cade, T. J. 1967. Ecological and behavioral aspects of predation by the Northern Shrike. Living Bird $6: 43-86$.

Lawrence, A. G. 1926. A butcher from the northland. Chickadee Notes No. 250. Winnipeg Free Press, January 7, 1926.

McNicholl, M. K. 1971. The breeding biology and ecology of Forster's Tern (Sterna forsteri) at Delta, Manitoba. Unpubl. M.Sc. thesis, University of Manitoba. $652 \mathrm{pp}$.

Mester, H. 1965. Feeding habits of the Great Grey Shrike in winter. British Birds. $58: 375-383$.
Miller, A. H. 1931. Systematic revision and natural history of the American shrikes (Lanius). California Univ. Publ. in Zoology. $38: 11-242$.

Thielcke, G. 1956. Zum Beuteverhalten des Raubwurgers (Lanius excubitor L.) und anderer Mausejager. Zeitschr. Tierpsych. $13: 272-277$.

Zimmerman, D. A. 1955. Notes on field identification and comparative behavior of shrikes in winter. Wilson Bull. $67: 20$ J-208.

\section{PILEATED WOODPECKERS NEAR DRUMHELLER, ALBERTA}

by John E. Storer, Provincial Museum and Archives of Alberta and Michael Wilson, Department of Geology, University of Wyoming

The Pileated Woodpecker (Dryocopus pileatus) occurs, according to Salt and Wilk (Birds of Alberta, 2nd Ed., 1966), "mainly in the mountains and in the northern and western parts" of Alberta. The only sighting in southeastern Alberta known to the authors is that of Randall (Can. Field-Nat., 60:123-131, 1946), who states that the Pileated Woodpecker is "An accidental and rare visitor in the fall" to the Brooks area. Thus sightings made in the Drumheller area may be of importance.

On July 6, 1971, the authors saw an adult Pileated Woodpecker (identified as a female by M. Wilson) foraging on the ground along a fallen log: close approach and easy identification were possible. On July 11, Storer saw two adults in a tree at a greater distance. Both sightings were made in a mature stream-bank stand of cottonwood at the Bleriot Ferry campground, about 10 miles northwest of Drumheller. Discussion with $\mathrm{Mr}$. Lloyd Heaton, one of the ferrymen, revealed that the birds have been seen in the vicinity of the ferry for several years.

The presence of these birds at the Bleriot Ferry over several years may indicate a range extension for the Pileated Woodpecker. Whether the Pileated Woodpecker is spreading down the Red Deer River, apparently the easiest route from its optimal range, to the Drumheller area cannot be determined without additional sighting's. 